\title{
A PROBLEMÁTICA EDUCAÇÃO DE ADMINISTRADORES
}

\author{
Carlos Osmar Bertero \\ Chefe do Departamento de Administração Geral e Recursos Humanos da FGV-EAESP
}

O debate sobre a pertinência e a qualidade da educação de administradores é quase tão antiga quanto o aparecimento das primeiras escolas e Programas de Administração de Negócios. No final da década de 1950, foi publicado o relatório de um trabalho financiado pela Ford Foundation, assinado por R. Gordon e J. Howell, Higher Education for Business, no qual já se registravam sérias críticas aos então recém-criados programas de MBA norteamericanos. As restrições, dúvidas e até mesmo ceticismo não impediram sua expansão. No Brasil, a explosão da educação em Administração foi vigorosa. Atualmente, há mais de 2000 cursos de graduação. Em paralelo, crescem no país os diversos programas de educação continuada, que aqui recebem as mais variadas designações, sendo a de maior popularidade o MBA à brasileira. Este, registre-se, pouco tem a ver com os originais americano e europeu.

A questão fundamental que os quatro artigos publicados neste fórum procura responder é se cursos de Administração de fato ensinam a administrar, ou, com o devido respeito a Platão: será que a virtude pode ser ensinada?

$\mathrm{O}$ artigo de Jeffrey Pfeffer e Christina Fong enfatiza o distanciamento entre o que acontece nas escolas de negócios e o que se pratica nas empresas. Lembra ainda que as pesquisas acadêmicas têm pequena repercussão e aplicação no mundo do profissional de Administração. Diante desta realidade, o futuro das escolas de negócios não parece assegurado, pois estas sofrem concorrência crescente de firmas de treinamento e de consultoria, as quais muitas vezes oferecem programas mais interessantes, e que são mais próximos da realidade da prática administrativa.

$\mathrm{O}$ artigo seguinte, de Henry Mintzberg e Jonathan Gosling, apresenta a experiência do Masters Program in Practicing Management. Segundo Mintzberg, o mundo das escolas de negócios e de seus cursos pouco tem a ver com o que administradores fazem em empresas. Seu programa fundamentase na reflexão sobre o trabalho dos administradores.

O terceiro trabalho, de Alexandre Nicolini, trata da educação em Administração no Brasil. Sua ênfase é sobre o fenômeno da expansão e possível impacto na formação dos administradores. Nicolini argumenta que faltaria aos ad- ministradores a capacidade crítica, a criatividade, isso em função da repetição de modelos, técnicas e idéias importadas. A inspiração de base é a retomada de aspectos do pensamento de Alberto Guerreiro Ramos e Paulo Freire.

O quarto artigo é de Roberto Ruas e trata de um curso ainda novo no nosso cenário educacional: o MPA - Mestrado Profissional em Administração - , que procura introduzir entre nós um programa profissionalizante na linha dos MBAs americanos e europeus. No Brasil, a sigla MBA é utilizada para designar cursos que se faz após a graduação, mas que não têm conteúdo, carga horária, nem requisitos acadêmicos definidos. Já o MPA oferece conteúdo cobrindo as diversas áreas funcionais da Administração, disciplinas instrumentais e ainda demanda um trabalho (dissertação) de conclusão de curso. Fazendo uso da experiência de dois programas de pós-graduação que oferecem MPAs, o artigo argumenta que o MPA supre uma lacuna de formação que não vem sendo coberta nem pelos programas de especialização (lato sensu) e nem pelos mestrados acadêmicos. Ruas sustenta para o MPA é em grande medida um programa que deve se aproximar do universo do profissional de Administração (gestor ou consultor) procurando conferir aplicabilidade aos conteúdos teóricos e conceituais.

A educação em Administração manifesta a fragilidade da própria Administração como área de conhecimento. $\mathrm{O}$ ensino de diversas profissões como a Engenharia e a Medicina, entre outras, está apoiado num cabedal de conhecimentos científicos que pela sua própria natureza acabam por abrir caminho à aplicação e à geração de técnicas e tecnologias. São essas aplicações ou desdobramentos do conhecimento científico que são ensinados nos programas que preparam os profissionais.

Os iniciadores da Administração Taylor e Fayol acreditavam na possibilidade de uma ciência da Administração que produziria conhecimentos e princípios que poderiam ser ensinados, apreendidos e aplicados. Tivesse isto acontecido e boa parte da literatura, bem como este fórum, talvez não existisse. Talvez nossos fundadores tenham sido um pouco ingênuos. Cabe perguntar se não herdamos de nossos fundadores parte dessa ingenuidade. 